\title{
Initiation of the last ice age in Canada by extreme precipitation resulting from a cascade of oceanic salinity increases
}

\author{
Robert G. Johnson \\ Department of Earth Sciences,University of Minnesota, Minneapolis \\ Minnesota, 55455 \\ glenjay@biitstream.net
}

\begin{abstract}
Numerical modeling has failed to confirm the classical Milankovitch hypothesis of initiation of the last ice age by Northern Hemisphere high latitude cooling due to decreasing summer insolation caused by orbital effects. The modeling failed to confirm ice sheet growth even with a widespread layer of glacial ice as an initial condition to embody positive feedback. The failure probably occurred because the initial conditions of the calculation did not include the actual effects of an altered climate in northeastern Canada that brought a sharp cooling to Europe and extreme amounts of precipitation to cloud-covered lands west of Greenland. In the conceptual model proposed here, diminishing orbital summer insolation in northern Africa is causally linked to this regional climate change by a cascade of oceanic salinity changes. The summer cooling in northern Africa weakened the monsoons, reduced the Nile River flow, and increased Mediterranean salinity and outflow at Gibraltar. The salt in the outflow contributes substantially to the salinities of the North Atlantic Drift and the Greenland Sea, to the formation rate of North Atlantic Deep Water (NADW) there, and to the northward flow of the Spitsbergen-Atlantic Current (SAC) that replaces the sinking NADW. When the increasing salt in the Mediterranean outflow made the SAC replacement flow sufficiently strong, the flow penetrated into the polar ocean along the north coast of Greenland. Denser and more saline Atlantic water then replaced the polar water flowing southward into Baffin Bay through the Nares Strait and Lancaster Sound, thus eliminating the stratification in the bay that enables freezing of winter sea ice. Without the southward flow of sea ice out of Baffin Bay, the Labrador Sea became much warmer. The warmer seas west of Greenland then triggered a persistent cyclonic circulation that caused large amounts of precipitation in eastern Canada and a much colder northern Europe. The resulting Canadian erosion yielded a 500yr-long deep-sea sediment record of the ice-free condition. Heavy snowfall started new ice sheet growth on Baffin Island, northern Quebec, Labrador, western Greenland, and the Barents Sea, causing world sea level to fall at a rate of $0.5 \mathrm{cmyr}^{-1}$. The modern increasing salinity of the Mediterranean Sea and extension of SAC flow into the polar ocean are now following the cascade steps toward an ice-free Baffin Bay and possible near term regional climate deterioration.
\end{abstract}

\section{Indexing terms/Keywords:}

Ice age initiation; Milankovitch; Bond oscillation; Ice age climate; Ice age climate change; orbital insolation change; next ice age;

\section{Academic Discipline And Sub-Disciplines:}

Earth Sccience, Paleoclimate change.

\section{SUBJECT CLASSIFICATION:}

Natural science.

\section{METHOD/APPROACH:}

Construction of a hypothesis of climate change from a synthesis of publlished research, new research, and analysis.

\section{Council for Innovative Research}

\author{
Peer Review Research Publishing System
}

Journal of Advances in Natural Sciences

Vol 3, No. 1

editorjansonline@gmail.com

www.cirworld.com 


\section{INTRODUCTION}

The initiation of new glaciation in northeastern Canada after the last interglacial cycle of the Pleistocene was a consequence of a climate change in northeastern Canada and Greenland (Fig. 1). The classical Milankovitch hypothesis[1] explained the change conceptually as a cooling caused by a decrease in orbitally-controlled northern summer insolation at about $65^{\circ} \mathrm{N}$ latitude. The Milankovitch idea that such insolation variations could be a generally controlling factor in ice age climate change had a wide appeal because of an assumed connection between insolation variations and ice sheet melting rates. This idea has been supported by many correlations between insolation changes calculated from Earth's orbital parameters and proxies for ice volume changes. These correlations have been useful in establishing valid time scales for Pleistocene events[2, 3]. However, the correlations do not ensure causal connections to climate or ice volume change. In a critical review of the contribution to observed climate change made by Milankovitch insolation forcing, Wunsch[4] concluded that in no case does orbital forcing explain the overall behavior of the proxy records, in particular the oxygen isotope ratio.

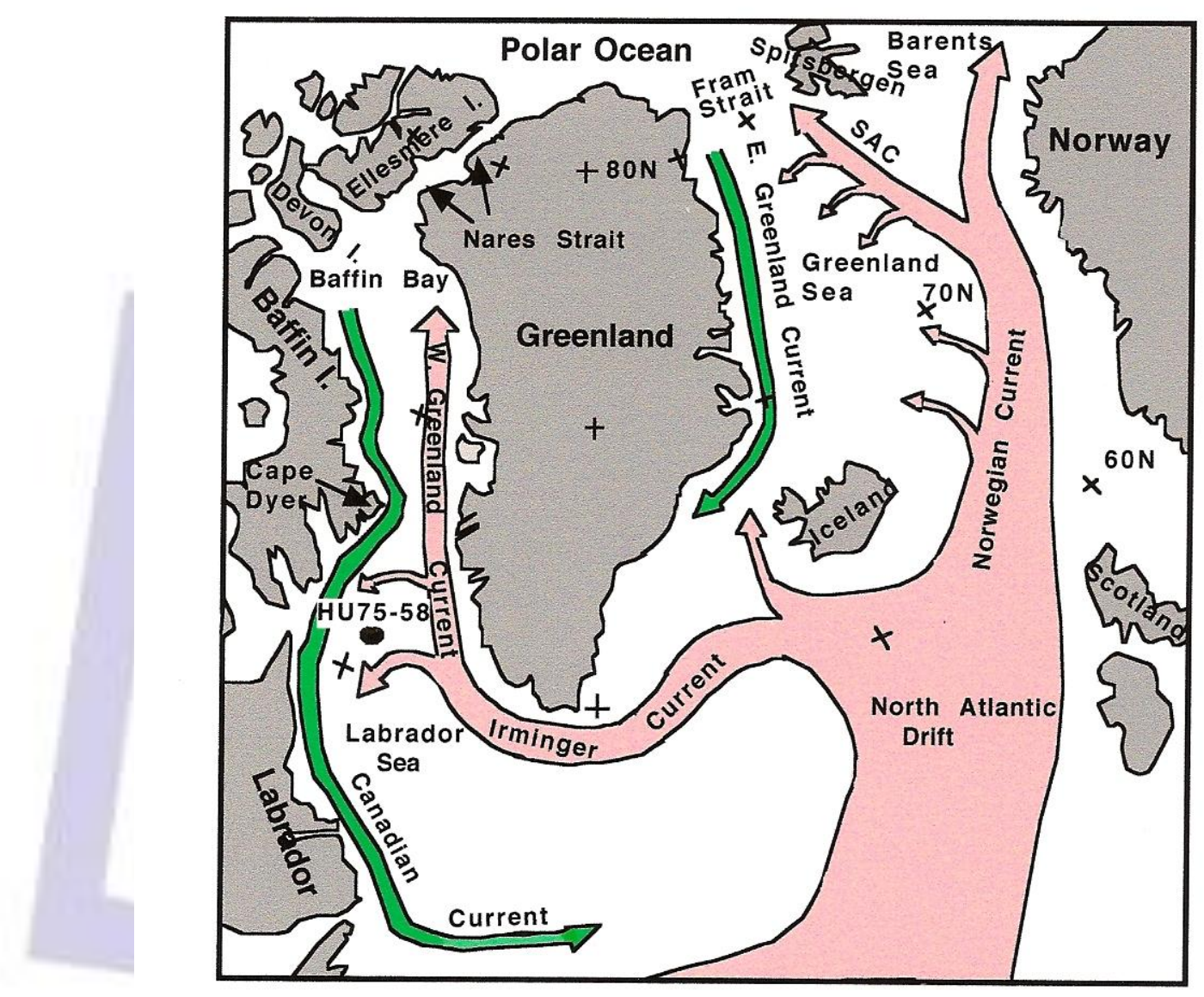

Figure 1 The high latitude northern North Atlantic showing the principal surface currents. The Spitsbergen-Atlantic Current (SAC) flows northward to replace the seasonal sinking of surface water that forms North Atlantic Deep Water (NADW) in the Greenland Sea.

The lack of an acceptable forcing connection has not alleviated the concern that an orbital insolation change might trigger a new ice age. Almost since its inception, the Milankovitch hypothesis has been thought to imply a possible near-future new ice age because of the assumed high latitude cooling due to decreasing insolation. This idea is supported by a comparison of the length of the last interglacial period to the current interglacial. Both have occurred under higher levels of falling orbital insolation. The present interglacial has endured for about 6000yrs since the melting of the great North American ice sheet ended. The last interglacial likewise lasted for about $6000 y r s[5,6]$ before new glaciation began in Canada. At its peak the caloric summer insolation at $65^{\circ} \mathrm{N}$ was $5 \%$ above that of today at $128,000 \mathrm{yr}$ BP. Today's insolation is now identical to that at $121,000 \mathrm{yr} \mathrm{BP}[7,8]$, and it is only $1 \%$ above that at $120,000 \mathrm{yr}$ BP when, within about a thousand year uncertainty, the last ice age began[6]. The Earth's climate system now appears to be poised at the boundary between the present interglacial and a possible future glacial climate. However, the future ice age threat has been greatly reduced by the recognition of modern climate warming by excessive atmospheric $\mathrm{CO}_{2}$. But the original simplistic Milankovitch 
hypothesis has not found support, and there has been yet much uncertainty as to precisely how the last ice age began. Therefore the near-future possibility of a new ice age inception should not be lightly dismissed.

The change in world sea level is generally a more reliable proxy for ice volume change than is the oceanic isotope ratio. However, the oceanic isotope ratio has provided much of the context of paleo climate and paleo oceanic change for the cascade hypothesis and it is important to realize that the isotope ratio has limitations. Therefore some of the difficulties in the use of oceanic isotope ratios are discussed in section 1 together with the bipolar oceanic oscillation as sidebar topics. Beginning in section 2 the cascade hypothesis is then developed before discussing its supporting evidence.

\section{[1] MILANKOVITCH STATISTICS, PROXIES, AND THE BIPOLAR OSCILLATION}

\section{[1.1] Statistical correlations support Milankovitch}

Despite contrary evidence, the simple Milankovitch concept has had a wide appeal because of the intuitively reasonable connection often assumed between insolation variation and melting rates. In addition, statistics based on two different proxies for world glacial ice volume support the possible orbital influence. Major change in world sea level is an accurate proxy but its record is usually only available at points in time near high sea stands that leave fossil reefs elevated and exposed on tectonically rising coasts. On the other hand the oxygen isotope ratio proxy for ice volume, as measured in skeletons of benthic foraminifera living at constant temperature in deep-sea sediments, provides a continuous record of ice volume change. Consequently the isotope ratio proxy in deep-sea cores has been exhaustively studied with well established but quite imperfect correlations between variations of calculated insolation at the top of the atmosphere and glacial ice volume. In a well known report by Hays, Imbrie, and Shackleton[7, 9] the periodicities of 23,000yrs due to orbital precession and an average of 45,000yrs due to Earth's axis obliquity are found in both the insolation variations and the ice volume proxy variations. These periodicities and other details strongly suggest that orbital variations are a factor in glacial ice volume change, although internal climate factors often mask orbital insolation effects.

\section{[1.2] Examples of internal climate factor dominance}

The effects of climate cooling caused by decreasing orbital insolation at high latitudes have been modeled numerically[10] but the results do not support the new glaciation that began about 120,000yr BP. Contrary to the predicted cooling, the ice sheet and marine sediment records described in sections 7.1 and 7.2 of this paper suggest that the last ice age began with marine temperatures in northeastern Canada that were warmer than today's and much warmer than earlier in the last interglacial[11, 12]. In a different context, high latitude insolation change also fails to explain the loss of glacial ice during one insolation minimum in which the loss caused world sea level to rise above that of today around 136,500yr BP[13, 14]. Nor does it explain why the last deglaciation began about $17,500 \mathrm{yr}$ BP in a much colder world with little more insolation than today[7, 15]. In contrast, Ruddiman and Mclntyre[16] found that the most rapid glacial ice volume increase occurred under warmer marine conditions in the subpolar North Atlantic. It is clear that internal factors within Earth's climate system, such as the moisture supply to glacial regions, can dominate the effects of orbital insolation variation. The threat of a modern ice age onset may still exist, and the precise mechanism of ice age inception is a question of much interest.

\section{[1.3] Proxy difficulties: the example of the anomalous deglacation}

Large changes of ice volume can occur due to internal climate effects that are unrelated to orbital insolation change. Unlike world sea level, the isotope ratio proxy may not always reflect a true change in ice volume. In one extreme example, melt water source effects can explain why the isotope ratio record indicated continuing full glacial ice volume while world sea level rose above that of today. This occurred in the anomalous deglaciation from probably about $142,000 \mathrm{yr}$ BP to $\sim 136,500 \mathrm{yr}$ BP[13, 14] when Northern summer insolation was near a minimum. At that time ice blocked the $\mathrm{Ob}$ and other Eurasian rivers flowing into the polar ocean except the Lena, and the blockage slowly formed a giant lake east of the Urals that was three times the area of today's Caspian Sea[17]. The deglaciation began when the rising lake broke through a sediment dam and flowed through the Aral, Caspian, and Black Seas[17] into the Mediterranean Sea. The Mediterranean outflow then effectively capped the high latitude North Atlantic with lower salinity water. This stopped NADW formation and probably sent the oceanic polar front southward to the latitude of Spain. Without the input of slightly warmer and more saline NADW injected into the mid level Southern Ocean, the Antarctic sea ice coverage would have expanded northward to an extreme lower latitude[18]. Consequently, with the North Atlantic oceanic polar front far to the south and the sea ice around Antarctica far to the north, storm paths were diverted to lower latitudes. This reduced the moisture supply to all the world ice sheets and the more arid ice sheet climates caused a continuing deglaciation. As measured by the differential uplift method on the stratigraphy of Barbados[13] and after a slight revision of the 2001 report, the resulting world sea level rise ended at an elevation of $+7 \mathrm{~m}$ above present at $136,500 \mathrm{yr}$ BP with an uncertainty of $\pm 1800 \mathrm{yrs}$. This method gives an age difference of 17,000 yrs between the $+7 \mathrm{~m}$ sea stand and the end of the interval of extreme precipitation in Canada when a brief sea stand occurred, see section 10. Henderson and Slowey[14] also reported evidence for a maximum high sea level close to the time of minimum insolation. This deglaciation and the $+7 \mathrm{~m}$ resulting high sea level have been largely ignored because the oceanic isotope ratio proxy remained positive in nearly all deep-sea cores regardless of location or site depth, thus incorrectly suggesting a full glacial ice volume. The anomalous deglaciation would have ended when the Ob river channel to the polar ocean became unblocked, drainage from the giant lake east of the Urals went northward, and significant melt water no longer entered the Mediterranean. Much Eurasian glacial ice then remained in place. The high sea level point was followed by a renewal of the Atlantic meridional overturning circulation and a rapid immediate reglaciation[19]. 
The observed high sea level is a reliable proxy, and a little speculation is needed to learn the reason for the fact that the isotope ratio proxy remained at the positive full glacial value. The world ocean apparently received melt water that was highly enriched in ${ }^{18} \mathrm{O}$ and which compensated for the usual tendency for melt water to diminish the ${ }^{18} \mathrm{O}$ concentration in the world ocean and move the isotope ratio to a more negative value. A source of such enriched water would have been the lake water east of the Ural Mountains that was discharged through the Mediterranean. Over a long period of time as the lake accumulated in the cold and arid climate, evaporative fractionation would have greatly enriched its ${ }^{18} \mathrm{O}$ content. When the sediment dam was washed away, the discharge flood passed through the Aral, Caspian, and Black Seas that had also been isolated and had become similarly enriched, and would have stratified the surface of the Mediterranean Sea with ${ }^{18} \mathrm{O}$ enriched water that was discharged through the Strait of Gibraltar. During the few thousand years of anomalous deglaciation the water from east of the Urals delivered the excess ${ }^{18} \mathrm{O}$ from the Ural paleo lake and the chain of seas to the world ocean. This probably compensated for the negative effect of other melt water sources that were normally deficient in ${ }^{18} \mathrm{O}$, and thus prevented the oceanic isotope ratio proxy from making a significant change from the observed full glacial value.

When reglaciation began and sea level fell[19], the chain of seas east of the Mediterranean once more became isolated. The enhanced ice sheet flow probably re-closed the Ob River channel, thus again isolating the giant lake. In an arid glacial climate the increase of $\mathrm{H}_{2}{ }^{18} \mathrm{O}$ in those seas and in the giant lake due to fractionation may have compensated for the additional positive isotope ratio effect in the world ocean due to the glacial accumulation until Termination II began.

\section{[1.4] The bipolar oscillation can delay ice age onset}

The anomalous shutdown of Antarctic Bottom Water formation was somewhat like today's low production of Antarctic Bottom Water during the spontaneous bipolar Bond oscillation[18]. The oscillation in the strength of the North Atlantic Drift reported by Bond et al.[20] is an integral part of the more extensive 1500yr bipolar Bond oscillation in the production rates of NADW and Antarctic Bottom Water during the interglacial. The oscillation has had only minor effects on the isotope ratio proxy, but it has played a part in starting the interval during which Baffin Bay was ice-free (Fig. 2). It also determines the duration of the ice-free interval, as outlined in section 9. It is discussed here as an important modifying factor before describing the cascade.

In the bipolar oscillation, slightly warmer NADW enters the Southern Ocean and provides positive feedback by increasing the rate of lower-salinity Antarctic Bottom Water formation. Antarctic Bottom Water enters the high latitude North Atlantic and provides negative feedback by lowering surface salinity and decreasing the rate of NADW formation in the Greenland Sea. Delays due to accumulation in respective mid level and bottom level reservoirs enable the oscillation. The negative feedback of lower salinity Antarctic Bottom Water entering the Greenland Sea in the sinusoidal model of the bipolar oscillation[18] could have delayed the onset of the ice-free Baffin Bay at the end of the last interglacial by almost $1500 y$ rs by reducing Greenland Sea salinity.

It is instructive to consider the two paths by which the Antarctic Bottom Water reaches the Greenland Sea surface. Mixed Antarctic Bottom Water is found in deep coastal locations just west of Spain and northern Africa where depths occasionally exceed $5000 \mathrm{~m}$. Although the deeper benthic drift is northward, the surface levels move southward. Consequently the geostrophic (coriolis) effect combines with trade wind stresses to move surface water away from the coasts. This lowers the pressure and allows Antarctic Bottom water to move upward toward the surface. As it rises, some of it mixes into the Mediterranean outflow water at the $\sim 1300 \mathrm{~m}$-depth west of Spain. That component is then carried quickly northward and upward in the higher salinity mixture that reaches the vicinity of northern Scotland as depicted by Reid[21], and discussed in detail in section 3.1. Reid reported evidence for the component of Antarctic Bottom Water in the form of trace concentrations of dissolved silica above the Scotland Faeroe sill that were four times the amounts found elsewhere in North Atlantic surface water. The other component of Antarctic Bottom Water that upwells along the coasts would mix into the entire surface area of the sub polar North Atlantic by way of trade wind currents and would tend to reduce the salinity of the Gulf Stream part of the North Atlantic Drift. That component therefore also tends to reduce the salinity of Greenland Sea surface and delay the following step in the cascade: the penetration of the SAC flow into the sea north of Greenland. The negative feedback of Antarctic Bottom water during the bipolar oscillation is therefore a significant timing factor in the connection between orbital insolation and ice age initiation proposed here.

The cascade of this paper builds on an earlier proposal by Johnson in 1997[22]. In addition to the bipolar oscillation, the new factors discussed here include data obtained from the high-resolution ENVISAT satellite observation system operated by the European Space Agency from 1997 to 2012 and early medieval historical records that support the presence of SAC water along the north coast of Greenland, which is a major step in the cascade (Fig. 2).

\section{[2] STARTING THE CASCADE: FALLING INSOLATION AND RISING MEDITERRANEAN SALINITY}

The context for the ice age onset was derived from a regional climate of unusually strong African monsoons. The monsoons are driven by latitudinal atmospheric pressure differences caused by temperature-dependent density differences between the atmosphere over northern Africa and that over areas to the south of the equator. The strongest monsoons occur in Northern Hemisphere summer during interglacials when the orbital summer insolation is high and there is no Eurasian ice sheet to cool the northern African region. If the temperature/density responses to orbital insolation variations were everywhere the same, their effects on monsoons would be small. This follows because precession 
dominates the axis tilt effect at low latitudes, and the departures from present insolation values are often about the same across equatorial latitudes[7]. But vertical oceanic mixing tends to stabilize atmospheric temperatures over the ocean. Therefore at times of summer insolation maxima, reduction of density and pressure due to solar heating are greater over the large northern African land area than over the combined ocean and smaller land area to the south. When the monsoon season begins, the moisture carried northward would increase the humidity and the resulting greenhouse effect, thus amplifying the atmospheric temperature rise caused by the summer sun. This positive feedback may help to explain the strong effect that a modest orbital increase of $6 \%$ in maximum summer insolation would have on the strength of the African monsoons. Now monsoons extend northward to latitude $12^{\circ} \mathrm{N}$ in the east and $16^{\circ} \mathrm{N}$ in the west at the edge of the Sahara. But at $9000 \mathrm{yr}$ BP and during the last interglacial about 126,000yr BP, soon after Northern summer orbital insolation maxima, the entire Sahara was a vast savanna that was well watered by the monsoons [23, 24].

Because of greater river inputs at those times, the Mediterranean salinity would have been relatively low. The Mediterranean deep-sea sediment record confirms the effect of greater river discharge and heavier precipitation at times of insolation maxima over the last 300,000yrs. Strong monsoons greatly increased the Nile River flow, as indicated by dark sapropels in deeper sediments of the eastern Mediterranean[25]. Sapropels were formed when greater fresh water inflow that was enriched with nutrients increased organic productivity in the sea surface and stratified near-surface levels. The high inflow was mainly from the Nile. The stratification inhibited deep vertical circulation and oxidation of the dark organic components of the sediments that were derived from organisms living in the surface waters. The salinity of the Mediterranean outflow at Gibraltar at those times was relatively low, and its contribution to the high-latitude North Atlantic salinity was also lower. Therefore as the summer insolation diminished after 23,000yr cyclic peaks of orbital precession, the monsoons weakened, river inputs diminished and the net rate of Mediterranean evaporation loss $(E-P)$ increased. As a result following the strong insolation peaks, Mediterranean stratification became less, sapropel formation stopped, and the salinity of the Mediterranean Sea and the salinity and rate of its outflow increased.

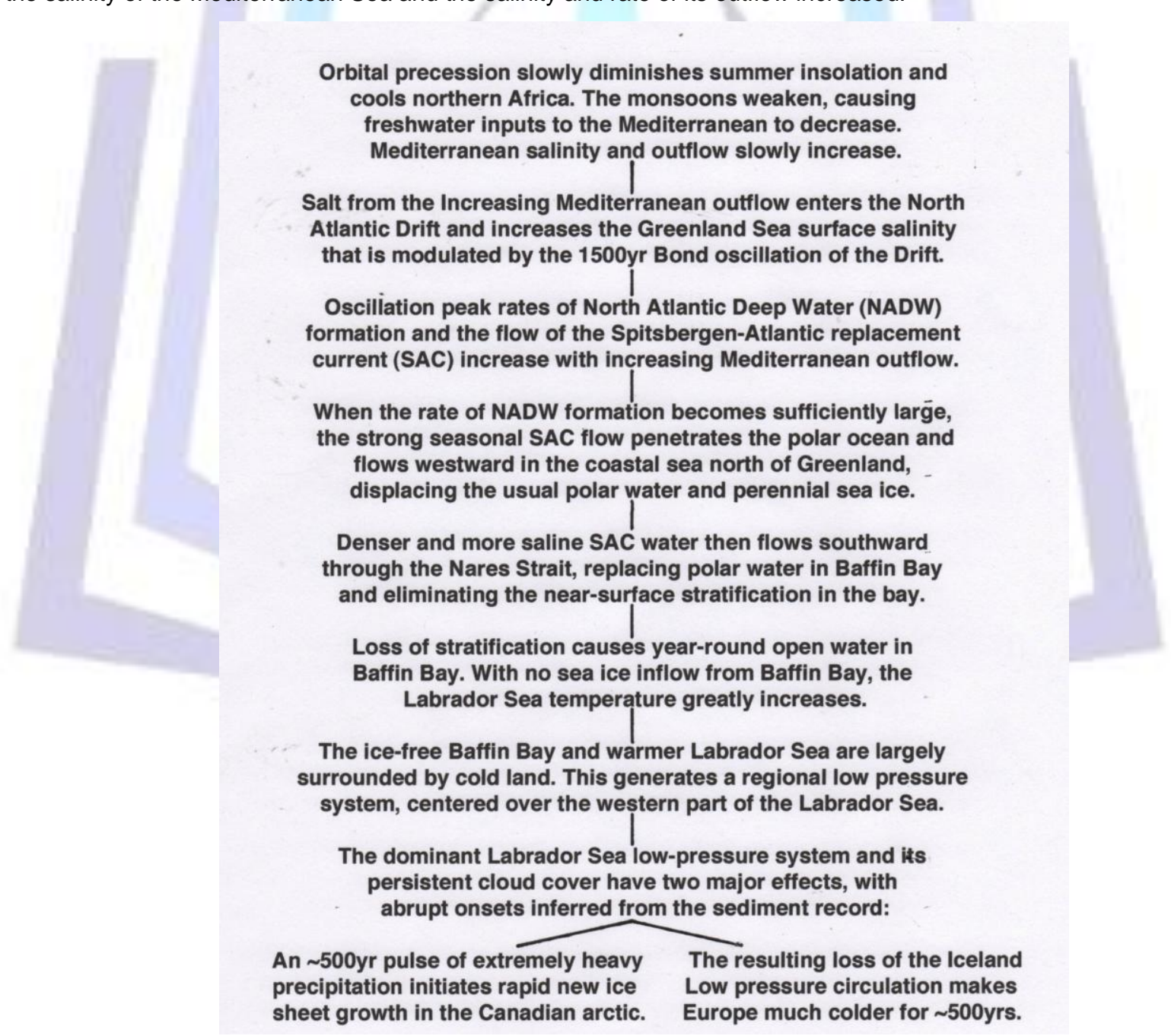

Figure 2 The cascade of oceanic effects that resulted in new Canadian glaciation at the end of the last interglacial. 


\section{[3] THE MEDITERRANEAN OUTFLOW CONNECTION TO NADW FORMATION AND SAC FLOW}

\section{[3.1]Generation and distribution of the outflow}

NADW forms from slightly warmer surface water in the Greenland Sea that is potentially denser because of its greater salt content. For a given winter temperature, the saltier the water the more rapidly it sinks when made denser by winter cooling, and the stronger is the northward SAC replacement flow from the Norwegian Current. The SAC flow rate therefore depends strongly on the salinity of the Mediterranean Sea and the part of its outflow that reaches the Greenland Sea. The outflow is part of the two-way exchange flow at Gibraltar[26] that balances the hydrologic budget of the Mediterranean arising from its dominant evaporation losses. Because of the losses, the salinity of the western Mediterranean is now about $2.4 \%$ greater than that of the adjacent North Atlantic[27], and with a similar temperature the Mediterranean water has a greater density. The density difference drives the outflow, and the denser outflow current sinks after it passes over the $285 \mathrm{~m}$-deep Gibraltar sill. As it sinks it mixes with Atlantic water west of Gibraltar and the mixture attains a buoyant equilibrium at depths over a range around $1300 \mathrm{~m}[27]$. The mixture forms a salinity maximum at that depth west of Spain that lies below and is distinct from the near-surface salinity maximum of the Gulf Stream water in the North Atlantic Drift[21]. One arm of the outflow mixture can be found nearly all the way across the Atlantic at the Gibraltar latitude. The other arm lying nearer to the British Isles extends northward beyond Scotland[27]. As that part of the mixture moves northward it rises and tends to mix into the Gulf Stream water of the North Atlantic Drift[21]. The combined mixture continues northeastward as the Norwegian Current, which supplies the SAC water to replace the sinking NADW. However, Mediterranean outflow water probably dominates Gulf Stream water in the Norwegian Current.

\section{[3.2] Proportions of Gulf Stream water and outflow water reaching the Greenland Sea}

Using salinity and temperature data to obtain density gradients, Greatbatch and $\mathrm{Xu}$ [29] calculated the northward velocities of Gulf Stream and Mediterranean mixtures over a vertical cross section at $54.5^{\circ} \mathrm{N}$ between longitudes $10^{\circ} \mathrm{W}$ and $35^{\circ} \mathrm{W}$ (Fig. 3). The velocity pattern together with the northward rise of the deep salinity maximum reported by Reid[21] west of Spain suggests that most of the water at this latitude east of $20^{\circ} \mathrm{W}$ and below $\sim 200 \mathrm{~m}$-depth may consist of the Mediterranean outflow mixture. By summing the incremental products of excess salinity from Worthington[30] and the velocities from Greatbatch and Xu[29] over the cross section at $54.5^{\circ} \mathrm{N}$, I estimate that the approximate proportion of excess salt in the Mediterranean mixture was about $37 \%$ of the total excess carried northward in the 1970-74 years. However, much of the Gulf Stream water lies to the west and feeds into the Irminger Current flowing westward (Figs. 1 and 3). Consequently, the Mediterranean water that reaches the surface east of northern Greenland where the NADW originates most likely dominates water from the Gulf Stream. An increase in the Mediterranean outflow at Gibraltar due to greater Mediterranean Sea salinity would therefore enable a corresponding significant increase in the Greenland Sea surface salinity, the rate of NADW formation, and the northward SAC flow of replacement water, with the caveat that the bipolar Bond oscillation will modulate the effect of the increase. The SAC flow into the sea north of Greenland, a necessary step in the cascade, would have occurred after an interval of increasing Mediterranean salinity and increasing SAC flow, and close to one of the approaching maxima in the salinity of the Greenland Sea caused by a minimal rate of injection of lower salinity Antarctic Bottom Water into the Greenland Sea during the bipolar Bond oscillation.

\section{[4] ATLANTIC WATER OF GREATER SALINITY NORTH OF GREENLAND}

\section{[4.1] Historical Data}

In the next step of the cascade model, the less dense fresher polar water that normally maintains a perennial sea ice cover off the northern coast of Greenland was replaced by somewhat warmer and potentially denser SAC water of greater salinity, thus eliminating the perennial sea ice there. There is evidence suggesting a weak flow of SAC water along the northern coast about 900yrs ago near the last bipolar Bond cycle maximum, but its effect was not strong enough to cause significant new glaciation. Open water then is inferred from archeological work and early medieval historical records. There is archeological evidence for Norse activity in the Kane Basin at $79^{\circ} \mathrm{N}$ (Figs. 1 and 4 ) in the form of chain male with woven cloth dated to $1260 \mathrm{AD}[31]$. A unique Jesuit map[32] from a Church archive, dated to 1599, shows a realistic outline of Greenland as an island. Other maps drawn by explorers of that time show Greenland attached to the North American continent because they were unable to sail into the perennial sea ice that enveloped the coast of northern Greenland after the Bond cycle maximum. However, the Jesuit map is likely a copy of information on an older map, now lost[32]. The lost map was probably drawn by Bishop Erik Gnupsson, a Norseman who is known to have visited northeastern North America, probably in a trading ship, in the years 1117 and 1118[33] during the time of warmer climate in the bipolar Bond oscillation. On the Jesuit map the Norse name "lotun heim" is attached to the Ellesmere area and is translated as "Home of the lotun." This name is apparently the bishop's name for the muskoxen of that area, and may have been derived from the Greek myth of lo, the goddess who was transformed into a heifer and roamed the world. This name supports the high probability that the bishop navigated the northern coast of Greenland in water free of the perennial sea ice that has since prevented ships with only sails from making that voyage. 


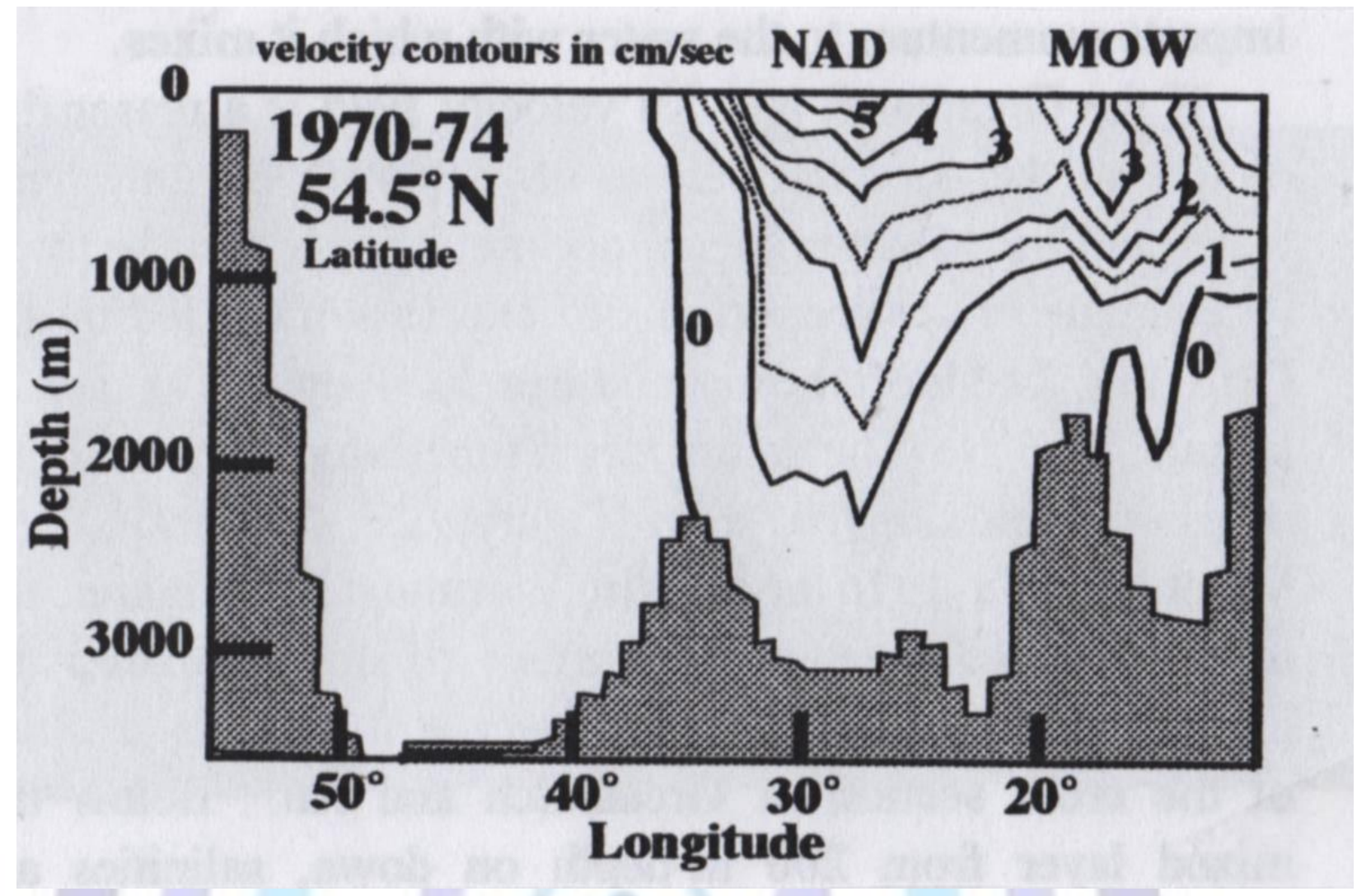

Figure 3 Northward Drift velocities across an oceanic cross section at $54.5^{\circ} \mathrm{N}$ calculated by Greatbatch and $X u[29]$ from temperature and salinity data acquired in the 1970-1974 years. Contours are in $\mathrm{cmsec}^{-1}$ Redrawn for clarity and used by permission from AGU. Although mixing does occur, the pattern of faster subsurface velocities suggests that the flow east of $20^{\circ} \mathrm{W}$ longitude is dominated by the salinity of the Mediterranean outflow (MOW).

\section{[4.2] Increasing Spitsbergen/Atlantic Current flow now penetrates the polar ocean}

Modern observations of NADW formation and the SAC replacement flow support the idea that unusually strong SAC flow brought Atlantic water to the north of Greenland. Since the middle of the Little Ice Age 250 years ago when SAC flow was weak, the seasonal northward penetration of the strengthening SAC flow has increased to the point that in mid winter the flow now reaches beyond the north coast of Spitsbergen. Figure 4 shows a series of satellite images of the SAC open water through the winter of 2014 when the flow reached as far as $83^{\circ} \mathrm{N}$ into the polar ocean, $\sim 340 \mathrm{~km}$ beyond the north coast of Spitsbergen. This occurred in mid February when sea surface temperature may be lowest and the rate of NADW formation is presumably at a maximum. For many days this extension of flow partially blocked the flow of polar ice from the north into the Fram Strait between Spitsbergen and Greenland.

It is unlikely that melt water from the Greenland ice sheet would inhibit the trend of increasing SAC flow. Unlike the warmer West Greenland Current, the East Greenland Current consists of cold polar ocean water that does not promote ice sheet melting. Furthermore, the dominance of the Mediterranean outflow mixture entering the Norwegian Current (Figs. 1 and 3 ) would largely determine the sea surface salinity in the area of NADW formation. Therefore in future decades the SAC will increase, and may completely block the polar water flow into the Fram Strait every winter. Seasonal pulses of Atlantic water would then join the westward circulation in the sea north of Greenland. Part of the SAC increase since the middle of the Little Ice Age about 1750 can be attributed to the cyclic increase of high latitude salinity during the bipolar Bond oscillation. But from about 1950 to 1990 the construction of dams has resulted in the capture of most Mediterranean river waters for irrigation. This loss of fresh water input may have caused most of the observed recent more rapid increase of salinity of about $0.11 \%$ at the $2000 \mathrm{~m}$-depth in the western Mediterranean over the last several decades, if extrapolated to year 2015[34]. This increase would be shared by the outflow at Gibraltar, and would be causing an $\sim 3.1 \%$ increase in the density difference between the Mediterranean and the Atlantic that drives the outflow at Gibraltar. Therefore the stronger penetration of the polar ocean by SAC flow in 2014 is likely due in part to an ongoing increase in Mediterranean salinity caused by modern society's use of Mediterranean rivers for irrigation. The Mediterranean salinity will continue its more rapid rise over the next hundred years while mixing moves the salinity toward a higher level dictated by the loss of river inputs. 


\section{ISSN 2393-9257}

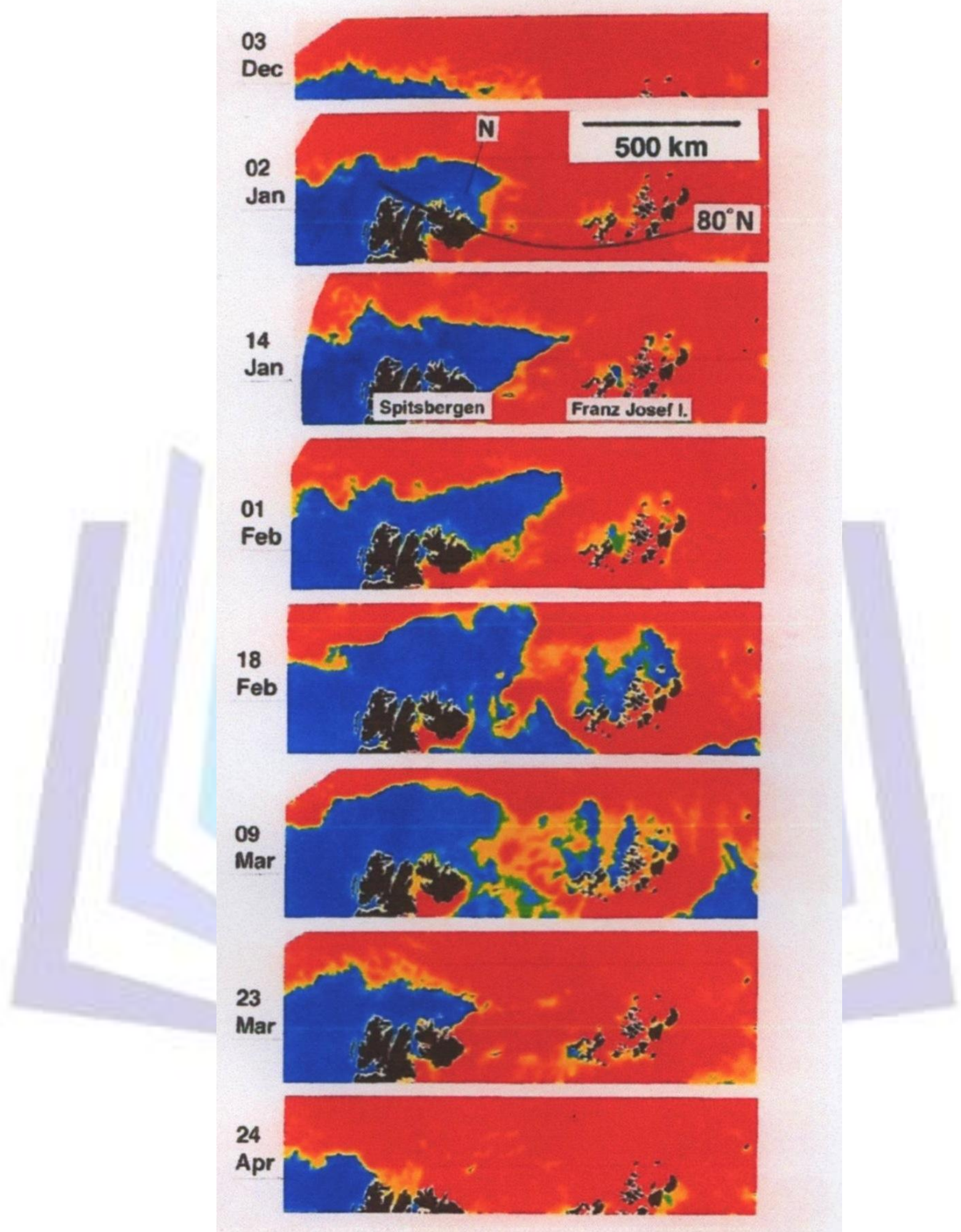

Figure 4 Penetration of the polar ocean by the Sspitsbergen/Atlantic Current during the winter of 2014 . Its northward flow beyond Spitsbergen tends to be deflected eastward by the southward flow of the polar current. Sea ice is false red color. The SAC flow is likely strongest in the coldest part of the winter about 18 February when surface water is sinking most rapidly to form North Atlantic Deep Water.

Therefore northern penetration of the winter SAC flow will likewise increase and may again put denser Atlantic water into the area along the northern coast of Greenland, with its flow into Baffin Bay. An extreme result might then be the loss of winter sea ice west of Greenland and a $\sim 500 \mathrm{yr}$ interval of new ice sheet growth on Baffin Island. To see how the loss of 
sea ice could have been maintained for 500yrs after the ice-free interval began at 120,000yr BP as discussed in section 6.2 , it is necessary to consider the flows into and out of Baffin Bay.

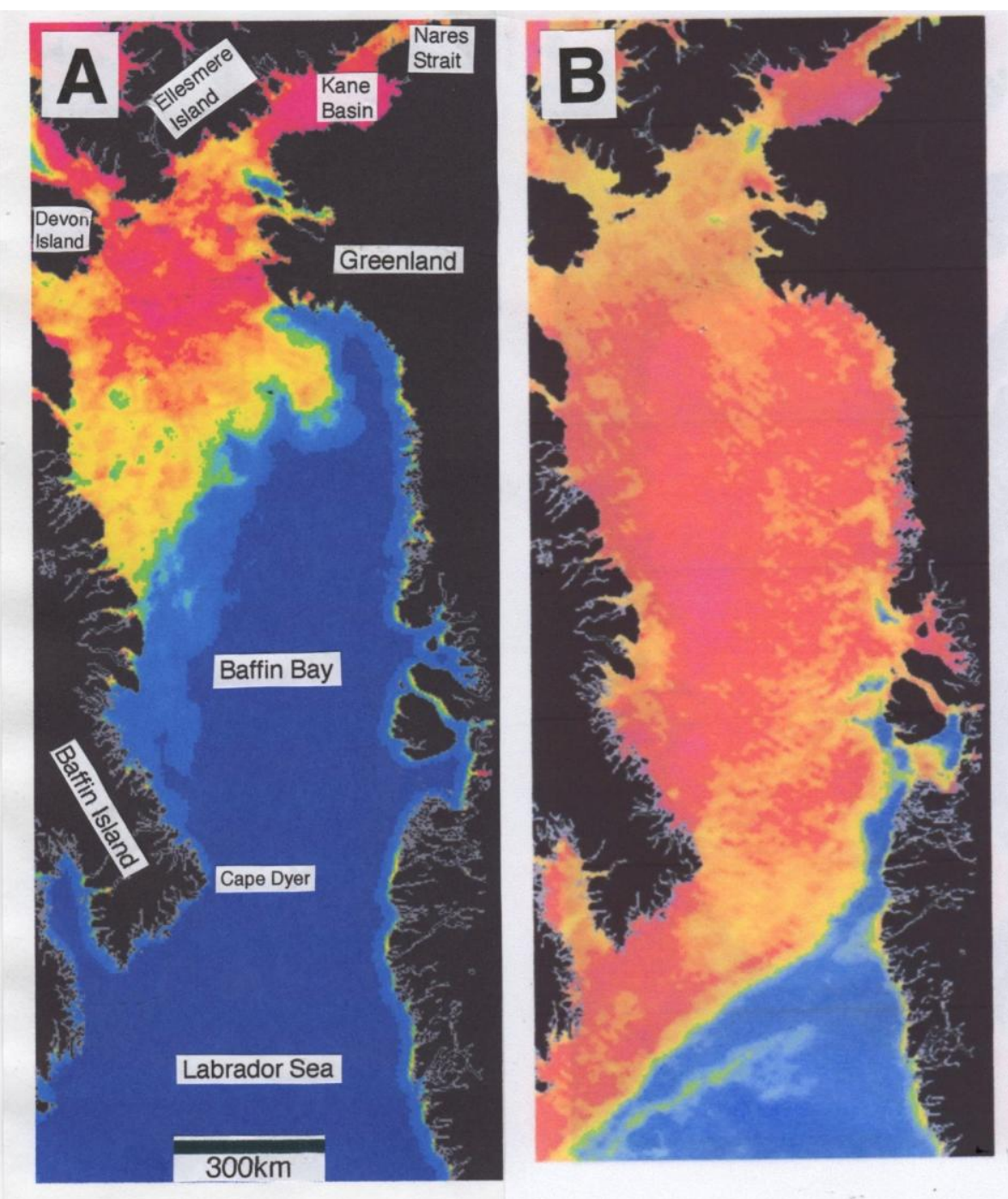

Figure 5 Typical seasonal sea ice coverage of Baffin Bay in red/yellow false color. A: 14 November, 2006. The first freezing occurs in the northern part of the bay where the stratification is the greatest due to lower density polar water inflow through the Nares Strait. B: 8 February, 2006. In mid winter the entire bay and much of the Labrador Sea north of Hudson Strait also becomes ice covered. There is then no movement of solidly frozen sea ice within the Nares Strait but subsurface inflow continues when favored by atmospheric pressure differences. Partly open water occurs at the southern end of the Kane Basin when flow over a sill causes turbulent mixing. ENVISAT images posted by the Technical University of Denmark.

\section{[5] MODERN BAFFIN BAY INFLOWS AND OUTFLOWS}

Baffin Bay is a $689,000 \mathrm{~km}^{2}$ area west of Greenland that extends northward from Cape Dyer to the Kane Basin at the south end of Nares Strait (Fig. 5). Depths are as great as $2000 \mathrm{~m}$ and, because the top layers are stratified by incoming polar water, it becomes covered with sea ice in winter as does much of the $200,000 \mathrm{~km}^{2}$ adjacent area of the Labrador Sea north of Hudson Strait. The West Greenland Current, an extension of the warmer Irminger Current, flows northward along the western coast of Greenland. Although it is greatly diminished by mixing in the Labrador Sea, its influence is still felt in Baffin Bay northward to the Kane Basin. The return flow of the mixed Canadian Current carries cold water and seasonal sea ice southward along the eastern coasts of Baffin Island and Labrador and keeps the Labrador Sea cold. Fresher and lower density polar water enters the bay through the Nares Strait. It flows turbulently over a sill at the southern end of the Kane Basin at the south end of the strait, leaving an area of frequent partly open water through the winter.

Using the high-resolution images of the ENVISAT satellite system through the year 2011 , I observed motion of large clumps of sea ice near the sill, and found that the flow through the strait is highly correlated with atmospheric pressure 
differences over the strait, with a dominant southward flow. During the summer season, disruption of pack ice patterns at the north end of the strait indicated an infrequent northward flow. On $56 \%$ of the 126 days when flow could be observed, the flow direction was southward with lower pressure over the bay. On 38\% the flow was northward with higher pressure, and on the remaining $6 \%$ the lack of pressure/flow agreement was on at least one occasion explainable by the enhancement of the West Greenland Current by wind stresses.

Small amounts of polar water also enter through Lancaster Sound between Baffin and Devon Islands. The resulting stratification is therefore greatest where polar water enters at the north end of the bay. Consequently the seasonal freezing of sea ice begins there (Fig. 5). As further cooling occurs, the freezing spreads over nearly all the less stratified sea area west of Greenland, including much of the Labrador Sea. The sea ice insulates the atmosphere from the warmer sea and tends to keep atmospheric temperatures low. But in the cascade model, an ice-free condition in Baffin Bay was triggered when, possibly for only a few decades, denser Atlantic water replaced the incoming polar water flowing southward through the Nares Strait.

\section{[6] AN ICE-FREE BAFFIN BAY: THE CAUSE OF REGIONAL CLIMATE CHANGE}

\section{[6.1] A strong low-pressure system over the Labrador Sea}

With denser Atlantic water entering both the north and south ends of Baffin Bay, the usual near-surface stratification was lost, and deep convection caused an ice-free sea in Baffin Bay throughout the winter. Without the southward flow of winter ice on the Canadian Current, the Irminger/West Greenland Current would have maintained a much warmer surface in the Labrador Sea. The Labrador Sea is roughly defined by the $1300 \mathrm{~km}$ distance from Cape Dyer to southern Labrador and the $900 \mathrm{~km}$ distance from southern Greenland to central Labrador. $70 \%$ of the periphery of this region is cold land in winter, and with no sea ice entering from Baffin Bay, the warm sea surface discussed in section 7.2 would have provided a remarkably sharp contrast to the surrounding cold lands. The neighboring Iceland area is not as well defined by coast lines and the temperature gradients there would have been weaker. Therefore a much stronger and more persistent lowpressure system would have occurred over the Labrador/Baffin area than occurred over Iceland, and its broad cyclonic circulation would not have allowed the Iceland Low to form. The points of lowest pressure were likely centered over northern Labrador on the western side of the Labrador Sea where sea/land temperature contrasts would have been maximized.

\section{[6.2] The persistence of the Labrador Sea Low cyclonic circulation}

The wind stresses of the cyclonic flow centered over the western part of the Labrador Sea would have enhanced the West Greenland Current, forcing warmer water into the north end of Baffin Bay, elevating sea level there, and reversing the southward flow through the Nares Strait that had triggered the ice-free sea. In a modern example, around 16 March 2012 and shortly before the failure of the high-resolution ENVISAT satellite system, I observed northward movements of large clumps of sea ice at the south end of the strait during a brief flow reversal when a transient cyclonic low-pressure system passed over southern Baffin Island. But despite the transient nature of weather patterns, the ancient sediment record of heavy precipitation suggests that a northward flow in the Nares Strait continued for centuries. When the SAC flow into the sea north of Greenland ceased after the initial triggering of the ice-free Baffin Bay, there was no effective interruption of outward flow then or over the next $~ 500 y r s$.

It is of interest to see how a cyclonic circulation could have been maintained in spite of the tendency for transient high latitude weather patterns to move eastward around the polar region. Even if the Labrador Sea Low suddenly vanished and the enhancement of the West Greenland Current ceased thus allowing lower density polar water to begin to flow southward through Nares Strait, stratification in the bay would not immediately be re-established. It would require $\sim 15$ days or more for the first of the polar water to traverse the $500 \mathrm{~km}$-length of the strait, plus an additional time to re-establish a stratified condition in Baffin Bay. Although temporary absences of the Labrador Sea Low system could have occurred, they would not have had a decisive effect if the Labrador Sea remained relatively warm and unstratified, thus allowing the strong cyclonic atmospheric flow to be quickly restored and enabling the northward flow of Baffin Bay water through the strait to resume. Even during the short summer season under cloudy skies in this cold part of the continent the thermal inertia of the surrounding snowfields may have kept the land colder than the sea, thus maintaining the cyclonic circulation and continuing snowfall. Consequently, the strong cyclonic circulation probably acted as a persistent blocking lowpressure system that could have disrupted normal westerly winds into Northern Europe during the 500yrs of heavy precipitation. Ice core and marine records support this picture of regional climate change.

\section{[7] EVIDENCE FOR THE EXTREME REGIONAL CLIMATE CHANGE}

\section{[7.1] Initial glaciation with a warmer Baffin Bay}

Evidence suggesting an increase in precipitation in the Baffin Island region precisely at the time new glaciation began has been found on Devon Island at the north end of Baffin Bay (Figs. 1 and 5). Although Devon Island became free of glacial ice during the last Canadian interglacial 126,000 -120,000yr BP, the icecap that formed during the most recent ice age has not melted away. An ice core extracted from this icecap extended down to bedrock[11]. When the new glaciation began, the relatively more negative oxygen isotope ratios of the lowest layers in the core showed that the ice was composed of snow that had precipitated under warmer conditions than snow in layers above. The lowest layers also contained wind- 
blown sediment and grains of willow pollen. In today's interglacial the closest willows are found at the Chantrey Inlet, about $800 \mathrm{~km}$ southwest of Devon Island[35]. The oxygen isotope ratios and pollen in ice at the base of the core therefore show that the usually severe interglacial winter climate of Devon Island had been replaced by a warmer regional climate, a climate explained by warmer open water in Baffin Bay.

\section{[7.2] A much warmer Labrador Sea}

Evidence for even greater sea surface warmth is found in the Labrador Sea about 200km east of southern Baffin Island (Fig. 1) at the site of core HU75-58[12] where winter sea ice prevails today. At the end of the last interglacial just before an abrupt shift toward glacially positive oxygen isotope ratios in foraminifera, a high $60 \%$ abundance of skeletons of warmer water sub polar species of foraminifera occurred in the core sediment (Fig. 6) after thousands of years of low abundance during the interglacial. Although the ice-free interval at the north end of Baffin Bay and this more extreme warmth of the Labrador Sea south of Cape Dyer are only approximately dated, it is most likely that they were concurrent, and were caused by the same regional change in oceanic and atmospheric circulation that began at 120,000yr BP at the end of the last interglacial.

\section{[7.3] A large precipitation increase caused much erosion}

The warmer open water west of Greenland would have provided a dynamic contrast to the surrounding cold lands of Greenland, Baffin Island, and Labrador/Quebec over most of the year. The resulting atmospheric pressure differences would have tended to generate a powerful cyclonic circulation around the seas west of Greenland. In the northern reaches of this system, heavy snowfall initiated new glaciation. To the south both heavy snowfall and heavy rain would be expected with resulting increased erosion. A high rate of erosion is indicated by an abrupt 500yr pulse of clay and red hematite-stained sand grains (Fig. 6). This pulse is found in the unique high-resolution record of core MD96-2036 from the Bermuda Rise, in which data points through the pulse occur at 125yr intervals. Deep currents carried these sediments from areas bordering the Labrador Sea and Baffin Bay[36].

Although the age of this unique pulse of sediments has not been measured precisely, it can be safely assumed that it was caused by the large increase in erosion associated with the onset of new glaciation west of Greenland that started the world sea level fall, dated accurately to $120,000 \mathrm{yr}$ BP by Stirling et al.[6]. The high rates of deposition of clay and hematite began together, but the deposition of the more mobile clay particles tapered off over a longer interval. Therefore, the part of the pulse consisting of the heavier hematite-stained sand component is probably the most reliable measure of the $500 \mathrm{yr}$ duration of the ice-free seas and heaviest regional precipitation.

\section{[7.4] Minimal summer melting and rapid erosion}

The 500yr deep-sea sediment pulse from the Bermuda rise required major erosion, caused by an order of magnitude increase in rainfall and melted snow in northeastern Canada. But rapid ice sheet growth requires that a significant amount of annual snowfall must remain unmelted. These seemingly conflicting requirements may be reconciled if the Labrador Sea Low had a frequent and almost stationary front that extended to the south over the Canadian coastal region. The heavy precipitation along the front could have supplied much of the eroded sand and sediment while to the north under the cyclonic circulation an 


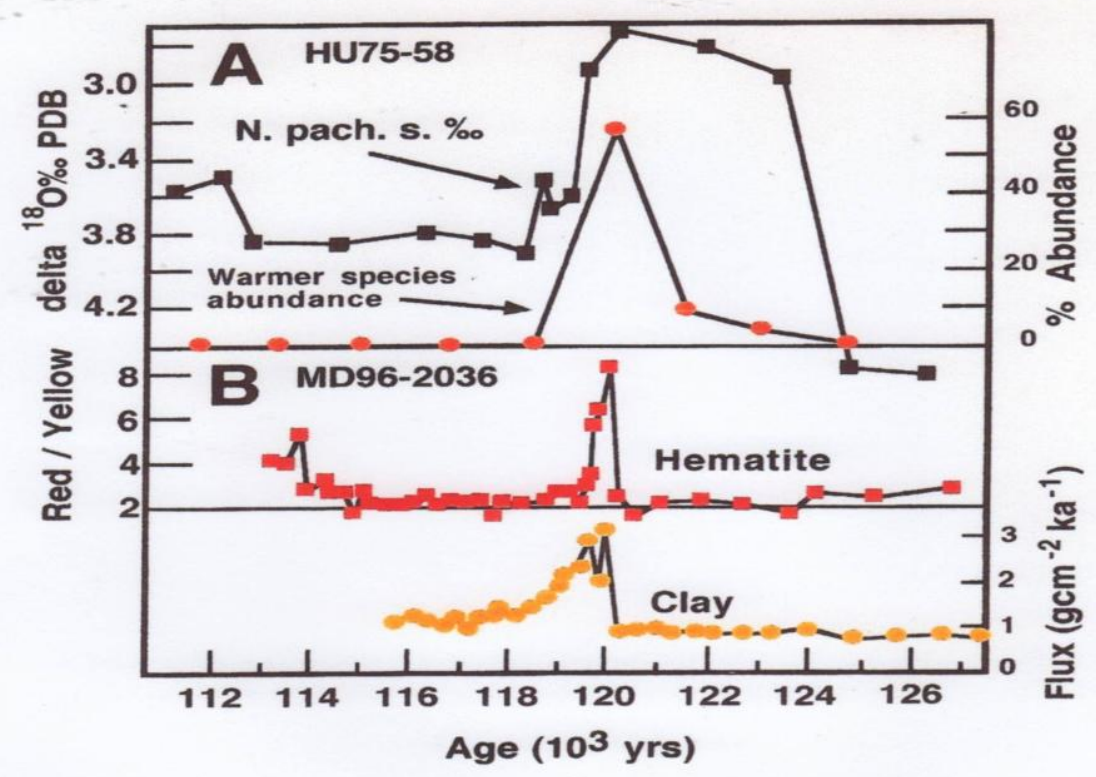

Figure 6 Deep-sea sediment evidence for warmer sea surface temperatures and quite heavy precipitation at the threshold of the last ice age, 120,000yr BP. A: Oxygen isotope ratios and abundance of subpolar foraminifera $\sim 200 \mathrm{~km}$ east of southern Baffin Island. From Fillon[12]. B: Pulse of clay and hematite-stained sand from the Bermuda rise indicating large amounts of erosion in northeastern Canada. From Adkins et al.[36]. The threshold age is set at 120,000yr BP to be consistent with the ice age onset obtained from youngest Australian corals on a slightly elevated fossil reef[6].

\begin{abstract}
unending supply of clouds minimized solar insolation at ground level. Consequently on Baffin Island in this coldest part of the continent most of the heavy snowfall may have remained unmelted. To explain a measurement that indicates an annual rate of about $0.5 \mathrm{cmyr}^{-1}$ of sea level fall during the first $500 \mathrm{yrs}$ as discussed in section 10 , a rough estimate suggests that an annual un-melted water-equivalent average depth of $0.9 \mathrm{~m}$ (about $10 \mathrm{~m}$ of snow depth) over the $1.96 \times 10^{6} \mathrm{~km}^{2}$ combined areas of Devon Island, Baffin Island, Labrador/Quebec north of $57.5^{\circ} \mathrm{N}$ latitude, Greenland west of $45^{\circ} \mathrm{W}$ longitude, and the Barents Sea ice dome would be needed. Although this is a high rate, it is not beyond serious consideration, and would be somewhat less if accumulation on Scandinavia had been included in the estimate.
\end{abstract}

\title{
[8] DOWNSTREAM EFFECTS: NORTHERN EUROPE AND THE BARENTS SEA
}

A broad cyclonic atmospheric flow anchored over the warmer Labrador Sea area of low pressure would have prevented the development of the adjacent Iceland Low pressure system to the east. Today the wind stresses of the cyclonic flow around the south part of the Iceland Low tend to inhibit the westward flow of the Irminger current, while enhancing the North Atlantic Drift and the Norwegian Current. Without the Iceland Low, a stronger Irminger Current may have contributed to the increase in the surface temperature of the Labrador Sea as implied by the $60 \%$ subpolar forminiferal abundance in Figure 6 . The absence of the Iceland Low and presence of a blocking Labrador Sea Low would also have diminished the atmospheric heat that is now carried into northern Europe by prevailing west winds. With a weaker Norwegian Current and less frequent westerly winds, northern Europe became much colder. In a lake sediment record from northern Germany[37], the pollen of temperate climate tree species of oak, elm, and linden nearly vanished(Fig. 7). However, the pollen record shows that warmer conditions subsequently returned. During the 2000yrs following 120,000yr BP there was a partial recovery of linden and elm and a lasting abundance 


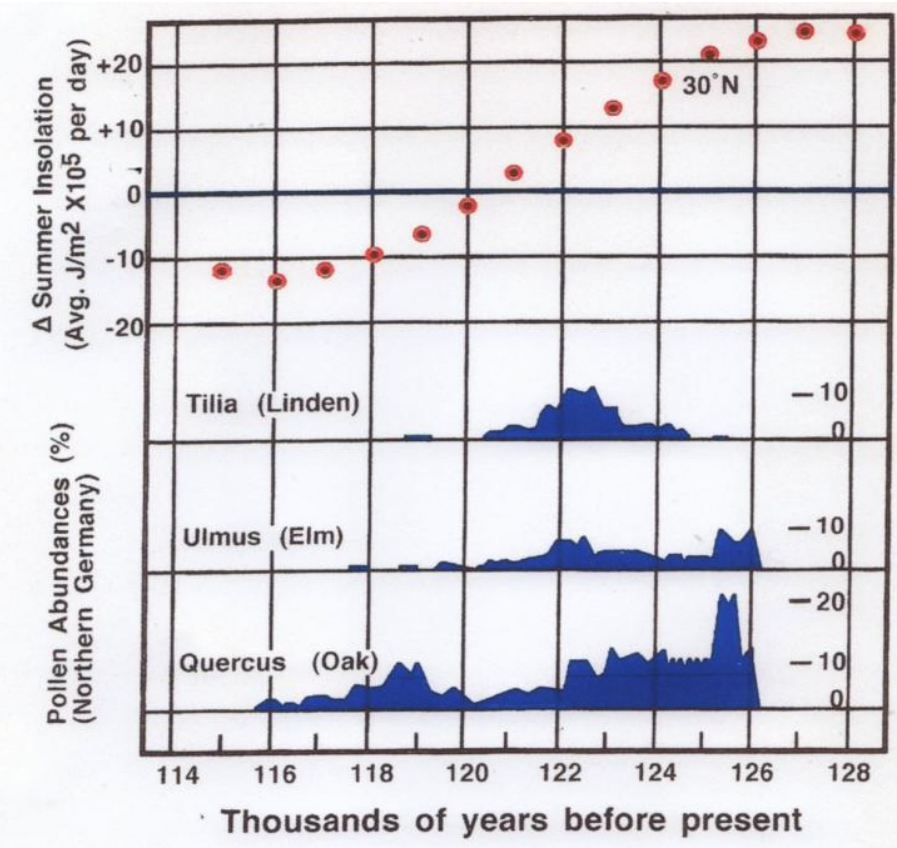

Figure 7 Last interglacial abundances of pollen of temperate climate trees from a lake in northern Germany from Field et al.[37] compared to differences of caloric summer insolation at $30^{\circ} \mathrm{N}$ relative to 1950. Insolation values from tables calculated and supplied by Berger[7]. The time scale is based on the accurately calculated insolation values. The interglacial minimum in temperate tree pollen is set just before the ice age onset, dated in Australian corals by Stirling et al.[6]. Although somewhat cooler toward its end, the last interglacial period in northern Europe was nearly 4000yrs longer than in northeastern Canada, and extended into the following insolation minimum at $65^{\circ} \mathrm{N}$. The European interglacial was probably terminated when the first Hudson Strait ice dam of the last ice age collapsed and flooded the subpolar North Atlantic with fresh water from the Hudson Bay region, thus diminishing or stopping North Atlantic Deep Water formation[39].

of oak. Then up to about $116,000 \mathrm{yr}$ BP a modest amount of only oak was recorded before the climate became glacially cold in Germany.

During the 500yr interval of severe cold in northern Europe, the cold regional climate would have favored a permanent ice cover on the shallow Barents Sea between Spitsbergen, Norway, and Novaya Zemlya, an area about the size of Baffin Island. Even today in the shallower areas the water column cools to the freezing point and winter sea ice forms. Temperatures in the Barents Sea area would have been low, but storms would have continued to move through over a limited area of open water west of Scandinavia, bringing a generous supply of moisture and heavy snowfall to the frozen Barents Sea area. The probable result was a marine-based ice dome that formed in the Barents Sea, much like the glacial accumulation of the last ice age[38].

\section{[9] TERMINATING THE 500YRS OF EXTREME ICE SHEET GROWTH}

In the cascade model, the ice-free condition of the seas west of Greenland was initially triggered by the flow of denser Atlantic water into Baffin Bay through the Nares Strait, but was then maintained over the remainder of the 500yr interval by a northward outflow of Baffin Bay water through the strait and Lancaster Sound. The outflow was caused by the persistent cyclonic circulation, which depended in turn on the warm temperature of the Labrador Sea, maintained by a strong Irminger Current. The strength of that current depended at least in part on a continuing substantial rate of NADW formation. However, as the cycle of the bipolar Bond oscillation continued during the 500yr interval, the flow of lower salinity Antarctic Bottom Water into the northern North Atlantic increased, thus decreasing the rate of NADW formation, the strength of the Irminger Current, and the temperature of the Labrador Sea. Eventually, with a cooler Labrador Sea and smaller cyclonic wind stresses, the weaker West Greenland Current became unable to prevent flow of polar water through the Nares Strait into Baffin Bay. The winter sea ice conditions abruptly returned, the Iceland Low pressure pattern resumed, and climate conditions indicated by tree pollen (Fig. 7) became almost as warm as before in northern Europe. 


\section{[10] AN ESTIMATE OF THE RATE OF WORLD SEA LEVEL FALL IN THE FIRST 50OYRS: THE BARBADOS DATA}

With the return of a more typically warm Norwegian Current, the potentially unstable marine-based Barents Sea ice dome would have broken up and melted. This probably halted the world sea level fall caused by continuing glacial ice accumulation in Canada. The paleo sea level record on tectonically uplifted Barbados[13] suggests such an interruption in sea level fall. On Barbados and other tropical sites during the $\sim 6000 y r s$ of nearly constant world sea level of the last interglacial, large accumulations of coral limestone debris often accumulated as reefs on shallow coastal substrates. Such reef accumulations typically have steep seaward slopes into deeper water. On the lee side of uplifted Barbados, the south and west coasts are in the trade wind rain shadow of the highlands. The reef record of past high sea stands there is remarkably well preserved because when sea level falls the minimal rain runoff dissolves small amounts of carbonate and re-deposits it within the interstices of the exposed coral sand and broken coral pieces, creating a solid limestone surface layer that resists erosion. On Barbados one prominent reef of particular interest is known locally as the First High Cliff. Its height is exceptional because the reef accumulated on top of a similar large coral deposit formed during the anomalous deglaciation in which world sea level was maximized around 136,500yr BP[13, 14].

During the reef buildup on a gently sloping substrate, optimal coral growth and the most rapid reef accumulation usually occur some distance from the shore. In this context during the long interglacial sea stands the reef buildup sometimes reaches the surface and forms a mature barrier reef with its top at the low tide level of the shoreline, from which it is separated by a shallow lagoon. An ideal mature configuration of fossilized barrier reef and lagoon is found on the flat top of the First High Cliff at the Cane Vale B site on Barbados, as described in a survey by Johnson[13]. At this site a shallow wave-cut notch with a $\sim 2 \mathrm{~m}$-broad step is found precisely at the seaward edge of the First High Cliff. The notch and step were eroded during a brief sea stand by waves breaking into the coral debris that had not yet been cemented by exposure to rain runoff. After a $0.1 \mathrm{~m}$ uplift correction, the step was found to be a measured $2.4 \mathrm{~m}$ below the adjacent mature barrier reef surface, and $2.7 \mathrm{~m}$ below the top of the nearby government survey marker S63-24 that rests on the barrier reef surface. The step marks the low tide level during a halt in falling sea level that quite probably occurred because of the melting of the Barents Sea ice dome. If so, the rate of world sea level fall due to glacial ice accumulation during the first 500 yrs of the last ice age was $0.5 \mathrm{cmyr}^{-1}$.

\section{SUMMARY}

The first glaciation of the last ice age began because a cascade of oceanic changes caused ice-free seas and a strong semi permanent cyclonic circulation around the Labrador Sea and Baffin Bay. The result was an order of magnitude increase in unmelted annual snowfall under cloudy skies throughout the region. A weakening of the African monsoons started the cascade, which proceeded in steps that included an increase in Mediterranean salinity and outflow rate, a modulated increase in salinity of the surface of the Greenland Sea south of the Fram Strait, a brief increase in salinity of the coastal sea north of Greenland, and 500yrs of greater salinity in an ice-free Baffin Bay and Labrador Sea. Among the first consequences were rapid ice sheet growth in northeastern Canada and 500yrs of quite cold climate in northern Europe. Climate warming by excess atmospheric $\mathrm{CO}_{2}$ might make any near-future switch to new ice age glaciation unlikely. Nevertheless, the increasing salinity of the Mediterranean and the Greenland Seas and the penetration of the SAC flow into the polar ocean are now duplicating the steps of the cascade toward a possible year-round ice-free Baffin Bay.

\section{REFERENCES}

[1] Milankovitch, M., 1930, Mathematische klimalehre und astronomische theoerie der klimaschwankungen, in: Handbuch der Klamatologie, 1 (A). W. Kopen and R. Geiger (eds):Berlin Gebruder Borntraeger, p. 1-76.

[2] Shackleton, N.J., A. Berger, and W.R. Peltier, 1990, An alternative calibration of the lower Pleistocene Time Scale based on ODP site 677: Transactions of the Royal Society of Edinburgh: Earth Sciences, v. 81, p. 251-261.

[3] Johnson, R.G., 1982, Brunhes-Matuyama magnetic reversal dated at 790,000yr BP by marine-astronomical correlations: Quaternary Research, v. 17, p. 135-147.

[4] Wunsch, C, 2004, Quantitative estimate of the Milankovitch-forced contribution to observed Quaternary climate Change: Quaternary Science Reviews, v. 23, p. 1001-1012.

[5] Thunell, R.C and D.F. Williams,1982, Paleoceanographic events associated with termination II in the eastern Mediterranean: Oceanologica Acta, v. 5, No. 2, p. 229-233.

[6] Stirling, C.H. T.M. Esat, K, Lambeck and M.T. McCulloch, 1998, Timing and duration of the last interglacial. Evidence for a restricted interval of widespread coral reef growth: Earth and Planetary Science Letters, v. 160, p. 745-762.

[7] Berger, A.L., 1978, Long term variations of caloric summer insolation resulting from the Earth's orbital elements: Quaternary Research, v. 9, p. 139-167. Tabulated values, private communication. 
[8] Venekar, A.D., 1972, Long period global variations on incoming solar radiation: Meteorological Monographs, v. 12 , No. 34, American Meteorological Society.

[9] Hays, J.D., J. Imbrie and N. Shackleton, 1976, Variations in the Earth's orbit: Pacemaker of the Ice Ages: Science, v. 194, p. 1121-1132.

[10] Rind, D., D. Peteet and Kukla, 1989, Can Milankovitch orbital insolation initiate growth of ice sheets in a general circulation model?: Journal of Geophysical Research, v. 94, p. 12851-12871.

[11] Koerner, R.M., J.C. Bourgeois, and D.A. Fisher, 1988, Pollen analysis and discussion of time-scales in Canadian ice cores: Annals of Glaciology, v. 110, 85-91.

[12] Fillon, R.H., 1985, Northwest Labrador Sea stratigraphy, sand input and paleoceanography during the last 160,000 years: in: Quaternary Environments, Eastern Canadian Arctic, Baffin Bay and Western Greenland, J.T. Andrews, ed, Allen and Unwin, Boston, p. 212-247.

[13] Johnson, R.G., 2001, Last interglacial sea stands on Barbados and an early anomalous deglaciation timed by differential uplift: Journal of Geophysical Research, v. 106, No.C6, p. 11543-11551.

[14] Henderson, G.M., and N.C. Slowey, 2000, Evidence from U-Th dating against Northern Hemisphere forcing of the penultimate deglaciation: Nature, v. 404, p. 61-66.

[15] Rind, D., and D. Peteet, 1985, Terrestrial conditions at the last glacial maximum and CLIMAP sea-surface temperature estimates: Are they consistent?: Quaternary Research, v.26, p. 1-22, doi:10.1016/0033-5894(85)90080-8.

[16] Ruddiman, W.F., and A. McIntyre, 1979, Warmth of subpolar North Atlantic Ocean during Northern Hemisphere icesheet growth: Science, v. 204, p. 173-175.

[17] Arkhipov, S.A., Ehlers, J., Johnson, R.G., and Wright, H.E., 1995, Glacial drainage towards the Mediterranean during Middle and Late Pleistocene: Boreas, v. 24, p. 196-206.

[18] Johnson, R.G., 2015, Did a bi-polar multi-level oceanic oscillation cause the Little Ice Age and other high latitude climate extremes?: Journal of Advances in Natural Sciences, v. 33, \#1, p. 228-236.

[19] Esat, T.M., M.T. Mculloch, J.Chappell, B. Pillans, and A. Omura, 1999, Rapid fluctuations in sea level recorded at Huon Peninsula during the penultimate deglaciation: Science, v. 283, p. 197-201.

[20] Bond, G., W. Showers, M. Cheeseby, R. Lotti, P. Almasi, P. deMenocal, P. Priore, H. Cullen, I Hadjas and G. Bonani, 1997, A pervasive millennial-scale cycle in North Atlantic Holocene and glacial climates: Science, v. 278, p. $1257-1266$.

[21] Reid, J.. 1979, On the contribution of the Mediterranean Sea outflow to the Norwegian-Greenland Sea: Deep-Sea Research, v. 26, p. 1199-1223.

[22] Johnson, R.G., 1997, Ice age initiation by an ocean-atmospheric circulation change in the Labrador Sea: Earth and Planetary Science Letters, v. 148, p. 367-379.

[23] Rossignol-Strick, M., 1983, African monsoons, an immediate climate response to orbital insolation: Nature 304, p. 4649.

[24] Rossignol-Strick, M., M. Paterne, F.C. Bassinot, K.-C. Emeis and G.J. De Lange, 1998, An unusual monsoon period over Africa and Asia: Nature, v. 392, p. 269-272

[25] Rossignol-Strick, M., 1985, Mediterranean sapropels, an immediate response of the African monsoon to variation of insolation: Palaeogeography, Palaeoclimatology, Palaeoecology, v. 49, 237-263.

[26] Bryden, H.L. and T.H. Kinder, 1991, Steady two-layer exchange through the Strait of Gibraltar: Deep-Sea Research, v. 38, Suppl. 1, p. 5445-5463.

[27] Price, J.F., M.O. Baringer, R.G. Lueck, G.C. Johnson, I. Ambar, G. Parrilla, A. Cantos, M.A. Kennelly and T.B. Sanford, 1993, Mediterranean Outflow Mixing and Dynamics: Science, v. 259, p. 1277-1282.

[28] Loubere, P., 1987, Changes in mid-depth North Atlantic and Mediterranean circulation during the late Pliocene Isotopic and sedimentological evidence: Marine Geology, v. 77, p. 15-38.

[29] Greatbatch, R.J., and J. Xu, 1993, On the transport of volume and heat through sections across the North Atlantic: Climatology and the pentads 1955-1959, 1970-1974: Journall of. Geophysical Research, v. 98, p. 10126-10143.

251 | P a g e 
[30] Worthington, L.V., 1976, On the North Atlantic Circulation: Johns Hopkins University Press, Baltimore.

[31] Schledermann, P., 2000, Ellesmere: Vikings in the far north, in: Vikings: The North Atlantic Saga, W.W. Fitzhugh and E.I. Ward, eds, Smithsonian Institution Press, Washington, p. 248-256.

[32] Ingstad, H., 1969, Westward to Vinland: St. Martins Press, New York.

[33] Skelton, T.A., T.E. Marston, and G.D. Painter, 1965, The Vinland Map and the Tartar Relation: Yale University Press, New Haven, p. 224-255.

[34] Rohling, E.J. and H.L. Bryden, 1992, Man-induced Salinity and Temperature increases in Western Mediterranean Deep Water: Journal of Geophysical Research, v. 97, p. 11191-11198.

[35] Short, S.K., W.N. Mode and P.T. Davis, 1985, The Holocene record from Baffin Island: modern and fossil pollen studies: in Quaternary Environments: Eastern Canadian arctic, Baffin Bay and Western Greenland: J.T. Andrews, ed, Allen and Unwin, Boston, p. 608-642.

[36] Adkins, J.F., E.A. Boyle, L. Keigwin and E. Cortijo, 1997, Variability of North Atlantic thermohaline circulation during the last glacial period: Nature, v. 390, p. 154-156.

[37] Fiield, M.H., B. Huntley and H. Müller, 1994, Eemian climate fluctuations observed in a European pollen record: Nature, v. 371, p. 779-783.

[38] Kvasov, D.D., and A. I. Blazhchishin, 1978, The key to sources of the Pliocene and Pleistocene glaciation is at the bottom of the Barents Sea: Nature, v. 273, p. 138-140.

[39] Johnson, R.G., and S.-E. Lauritzen, 1995, Hudson Bay and Hudson Strait jokulhlaups and Heinrich events: a hypothesis: Palaeogeography, Palaeoclimatology, Palaeoecology, v. 117, p. 123-137. 